International Journal of STEM Education for Sustainability, Vol 2, No.2, 2022, pp. 140-147

e-ISSN 2798-5091. DOI. 10.53889/ijses.v2i2.54

\title{
The Relationship Between Motivation and Learning Outcomes of Biology Subject Through Distance Learning
}

\author{
Submitted 15 January 2022 Revised 29 January 2022 Accepted 30 January 2022 \\ Feni Julia Salsa ${ }^{1 *}$, Rona Taula Sari $^{2}$, Nawir Muhar ${ }^{3}$, Gusmaweti Gusmaweti ${ }^{4}$ \\ Biology Education Program, Faculty of Teacher Training and Education, \\ Universitas Bung Hatta, Padang, Indonesia \\ Corresponding Email: *fenijuliasalsa7@gmail.com
}

\begin{abstract}
This study aimed to determine the relationship between motivation and biology learning outcomes through distance learning in senior high school in Indonesia. The change in the face-to-face learning process to distance learning since the Covid-19 pandemic has had an impact on learning motivation that affects student learning outcomes. This type of research is descriptive with quantitative research methods. The research was conducted at one high school in Indonesia. The research subject consist of 80 students. The sampling technique was simple random sampling, which was done randomly, using an error rate of 5\%. The data collection in this study used a questionnaire containing statements of students' learning motivation through distance learning using a Likert scale, and documents on students' biology learning outcomes in the odd midterm exams for the 2021/2022 academic year. The results of the Pearson product moment correlation test were obtained at 0.86 on intrinsic motivation and extrinsic motivation of 0.85 , meaning that there is a relationship between motivation and biology learning outcomes through distance learning. The results of the $\mathrm{t}$-test showed that the $\mathrm{t}$-count of intrinsic motivation was 15.27 and the t-count of extrinsic motivation was 14.47 , indicating that there was a significant relationship between motivation and learning outcomes of biology subject through distance learning. The coefficient of determination of intrinsic motivation is $75 \%$ and extrinsic motivation is $73 \%$, this means that intrinsic motivation (X1) and extrinsic motivation (X2) contribute to student biology learning outcomes (Y).
\end{abstract}

Keywords: Motivation, Biology learning outcomes, Distance learning

\section{INTRODUCTION}

Covid-19 is a disease outbreak that has become a global pandemic with a worrying spread. Indonesia is one of the countries that has felt the impact of this pandemic outbreak. The impact of Covid-19 has occurred in various fields, one of which is education. The quality of education is experiencing challenges during the pandemic outbreak, so the government has taken a policy to implement social distancing and physical distancing, namely an appeal to maintain distance and avoid activities that involve many people. This has changed the learning process, which initially took face-to-face in schools, requiring indirect learning, namely distance learning. Distance learning is carried out at home online.

When learning is carried out online, biology learning becomes limited. This has an impact on learning for both students and teachers, namely changes in the implementation of learning that require teachers to be more innovative in the implementation of distance learning by using online learning media and platforms that are only focused on providing materials and assignments with the limitation of explaining them directly to students and students are required 
to be able to study independently away from the teacher's supervision, where students feel burdened by the limited ability to understand biology lessons by themselves so that it affects student learning motivation.

This also happened to the students of class $\mathrm{X}$ at one high school in Indonesia. The implementation of online learning also affected students' learning motivation. Students' learning motivation is still low. This can be seen from the scores of the mid-semester exams in the cognitive domain of many incomplete students. This problem occurs because students are less motivated to learn online. It can be seen from the presence and participation of students who take part in online learning is only a little. The presence and attention of students in participating in online learning are very minimal compared to offline learning. This situation creates an unstable learning climate so that student learning motivation can decrease and affect student learning outcomes. The research results of Cahyani (2020) with the title "Learning Motivation of High School Students in Online Learning in the Covid-19 Pandemic Period" indicate that the learning motivation of students who take online learning or online during the Covid-19 virus pandemic situation is decreasing.

Many factors can influence student learning outcomes, one of which is learning motivation. High motivation in students to learn will have an impact on optimal learning outcomes. Sardiman (2014) said that high motivation students would have greater energy to carry out learning activities. Student success in education is seen from student learning outcomes. In line with Irsyad and Fauzy (2021), to find out the level of success in education, it is necessary to measure the learning outcomes obtained by students after the learning process. In this regard, this study aims to determine the relationship between motivation and learning outcomes of biology through distance learning.

\section{METHOD}

This research was conducted at one high school in Indonesia. The research subject consists of 80 students. The sampling technique was simple random sampling, done randomly, using an error rate of 5\%. There are two kinds of variables in this study, namely the independent and dependent variables. The independent variables in this study consisted of intrinsic learning motivation (X1) and extrinsic learning motivation (X2) through distance learning, while the dependent variable was learning outcomes (Y) through distance learning. The data collected in this study used a questionnaire containing statements of students' learning motivation in distance learning using a Likert scale and documents on students' biology scores in the odd midterm exams for the 2021/2022 academic year. Data collection using a student learning motivation questionnaire in distance learning using a Likert scale can be seen in Table 1. 
Table 1. Positive and Negative Statements on the Likert Scale

\begin{tabular}{lll}
\hline \multirow{2}{*}{ Alternative answer } & \multicolumn{2}{c}{ Score given } \\
\cline { 2 - 3 } & Negative & Positive \\
\hline Strongly agree & 1 & 5 \\
Agree & 2 & 4 \\
Doubtful & 3 & 3 \\
Disagree & 4 & 2 \\
Strongly disagree & 5 & 1 \\
\hline
\end{tabular}

Before the questionnaire was tested on students, validity and reliability tests were first carried out so that the data obtained from the questionnaire was valid and reliable. Furthermore, the data obtained were tested by descriptive analysis to determine the degree of achievement of each variable. A normality test is performed using the Kolmogorov Smirnov test to determine if the data is normally distributed or not. Then the homogeneity test was conducted to determine whether the data obtained were homogeneous or not.

To determine the relationship between motivation and learning outcomes of biology in distance learning, it can be known through the correlation test data analysis technique using the Pearson Product Moment Model correlation technique.

$$
r x y=\frac{\sum x y}{\sqrt{\left(\sum x^{2}\right)\left(\sum y^{2}\right)}}
$$

Description :

$r_{X Y} \quad=$ correlation coefficient

$\sum X^{2}=$ the sum of the squares of the respondents' instrument scores

$\Sigma_{\mathrm{Y}^{2}}=$ the sum of the squares of the sample midterm test scores

$\sum X Y=$ the sum of the products of $\mathrm{X}$ and $\mathrm{Y}$

(Sugiyono, 2017)

The value of $r$ will be consulted with the table of interpretation of the value of $r$ that can be seen in Table 2 .

Table 2. Interpretation of Correlation Coefficients

\begin{tabular}{ll} 
Coefficient Interval & Relationship Level \\
\hline $0,800-1,000$ & Very strong \\
$0,600-0,799$ & Strong \\
$0,400-0,599$ & Strong enough \\
$0,200-0,399$ & Low \\
$0,000-0,199$ & Very low \\
\hline
\end{tabular}

(Sugiyono, 2016) 
The significance of the product-moment correlation can be tested using the t-test to determine how much influence the independent variable $(\mathrm{X})$ has on the dependent variable $(\mathrm{Y})$ using the coefficient of determination formula.

\section{RESULTS AND DISCUSSION}

Research on the relationship between motivation and biology learning outcomes through distance learning has been carried out at one high school in Indonesia. In this study, 80 students were research subjects. Each respondent who is the sample in this study fills out a learning motivation questionnaire $(\mathrm{X})$ which consists of intrinsic motivation (X1) and extrinsic motivation (X2). Student biology learning outcomes (Y) were obtained from the odd midsemester exam scores for the 2021/2022 academic year.

Before the data was tested for correlation, it was first tested for validity, with the results of the validity test by linguists being 3.16 and the validity test results being 3.33 by content experts. This means that the learning motivation questionnaire on distance learning is declared valid. Furthermore, after calculating the reliability of learning motivation in distance learning (X) of 1.00, the instrument used has very high reliability. The results of the descriptive analysis test obtained the results of the calculation of the intrinsic motivation variable (X1) with a mean (average) value of 80.3; median (middle score) 80; mode (a score that appears the most) 81; standard deviation (standard deviation) 7.22; minimum score of 65; the maximum value is 110 . The degree of achievement of intrinsic motivation in distance learning of class $X$ at one high school in Indonesia, 59\%, is in a bad category. It can be seen from the lowest item score of student responses on the desire to learn indicator on the learning motivation questionnaire in distance learning that students are not indifferent to the biology material given by the teacher when learning online. As can be seen from the highest item scores, student responses to the desire to learn indicator on the learning motivation questionnaire in distance learning are that students prefer to study offline than online.

While the extrinsic motivation variable (X2) is also 59\%, then the degree of extrinsic motivation in distance learning for class $\mathrm{X}$ at one high school in Indonesia is in the bad category. This means that class X Mathematics and Natural Sciences students also have poor extrinsic motivation towards biology subjects in distance learning. It can be seen from the lowest item score of student responses on the indicator of knowing the results of the statement on the learning motivation questionnaire in distance learning that students still do not learn even though students' biology scores are not complete. As can be seen in the highest item scores of student responses to the indicators of competition/competition on the learning motivation 
questionnaire, distance learning students study hard because they want to get higher scores than their friends.

Likewise, descriptive data on learning outcomes variable (Y) shows $13 \%$ in the very poor category, which means that the degree of achievement of learning outcomes in distance learning for class $\mathrm{X}$ at one high school in Indonesia is very bad. This means that class X students have very poor learning outcomes for biology subjects in distance learning. It can be seen from the intrinsic motivation and extrinsic motivation of students' learning that during online learning, students are not indifferent to the biological material given by the teacher because students prefer to learn when learning is carried out offline. Then students will study hard if they want to get a higher biology score than their friends, but in fact, students still do not study even though their biology score is not complete. This causes students to have very poor learning outcomes for biology subjects in distance learning. Irsyad and Fauzy (2021) said that learning motivation makes students more active in learning and can take learning seriously. There will be no lag in receiving lessons.

On the contrary, if learning motivation is low, students will become passive, making students indifferent to lessons. The research results of Cahyani (2020) show that the motivation to learn in students who take part in online learning or online in the midst of the Covid-19 virus pandemic has decreased. Several factors affect the decline in learning motivation in students when viewed inherently with the learning situation during the Covid-19 period, both internal and external factors. Sardiman (2014) says that intrinsic motivation can be said as an impulse that comes from within a person to carry out learning activities to achieve the desired goals from the learning process he does. The driving force comes from need. The need that contains the necessity to become an educated and knowledgeable person, then students who have intrinsic motivation will have the goal of becoming an educated person, who is knowledgeable and masters skills in a particular field. While extrinsic motivation is active and functioning motives due to external stimuli. Extrinsic motivation can also be said as a form of motivation that is carried out because it wants to achieve goals that lie outside the things that are learned (Sardiman, 2014)

In line with that, Damopolii (2018) says that motivation has a relationship with learning outcomes. Student learning outcomes will be good because they have strong motivation. Learning outcomes are very important to determine the extent to which students' mastery of the material includes cognitive, affective, and psychomotor abilities. High learning outcomes describe the success of students in learning. Maryam (2016) said that students who have high learning motivation desire and drive to learn. Students who have the desire and drive to learn 
based on the need to achieve high learning outcomes are one of the guarantees to be able to complete the learning activities they take well.

The correlation test obtained a correlation coefficient of motivation to determine the relationship between learning motivation and learning outcomes. The following are the results of the person correlation test in Table 3.

Table 3. Correlation Coefficient Test Results

\begin{tabular}{llll}
\hline Variable & Correlation coefficient & $\mathrm{r}_{\text {table }}$ & Interpretation \\
\hline Intrinsic Motivation $\left(\mathrm{X}_{1}\right)$ & 0,86 & 0,22 & $\mathrm{H}_{1}$ Received \\
Extrinsic Motivation $\left(\mathrm{X}_{2}\right)$ & 0,85 & 0,22 & $\mathrm{H}_{1}$ Received \\
\hline
\end{tabular}

From Table 3, it is known that the correlation coefficient of the intrinsic motivation variable $(\mathrm{X} 1)$ is 0.86 , and the correlation coefficient of the extrinsic motivation variable (X2) is 0.85 . Thus it can be seen that the correlation coefficient of intrinsic motivation (X1) and the correlation coefficient of extrinsic motivation (X2) is more significant than $\mathrm{r}_{\text {table }}=0.22$. It can be stated that $\mathrm{H} 1$ is accepted and $\mathrm{H} 0$ is rejected. This means a relationship between motivation and biology learning outcomes in distance learning for class $\mathrm{X}$ at one high school in Indonesia.

This can also be seen in the t-test to see the significance of the relationship between the intrinsic motivation variable (X1) and the extrinsic motivation variable (X2) with the results obtained $t_{\text {count }}>t_{\text {table, }}$ which is $15.27>1.66$ for the intrinsic motivation variable $(\mathrm{X} 1)$ and 14.47 $>1.66$ for the extrinsic motivation variable (X2). There is a significant relationship between learning motivation and biology learning outcomes through distance learning for students of class $\mathrm{X}$ at one high school in Indonesia. The lower the student's learning motivation, the lower the student's biology learning outcomes. On the other hand, the higher the students' motivation to learn biology, the higher the student's biology learning outcomes. In line with Irsyad and Fauzy (2021) said that learning motivation encourages students to study with enthusiasm in achieving maximum learning outcomes, it will make students use their minds more in learning than thinking about other things because students who have learning motivation Higher education students will focus more on focusing their thoughts on paying attention to the teacher's explanation so that the material presented by the teacher can be well received. Sardiman (2014) explains that learning motivation can be said as the overall driving force within students that causes learning activities, which ensure the continuity of learning activities and provide direction to learning activities so that the desired goals are achieved. Students who have high motivation will have greater energy to carry out learning activities.

The correlation analysis in this study was continued by calculating the coefficient of determination. From the analyzed data obtained, the percentage of intrinsic motivation variable (X1) was $75 \%$, and extrinsic motivation (X2) was $73 \%$. This means that $75 \%$ of intrinsic 
motivation and $73 \%$ of extrinsic motivation contribute to student biology learning outcomes (Y) during the implementation of distance learning. Thus, motivation dramatically contributes to student biology learning outcomes in distance learning for class $X$ at one high school in Indonesia. Motivation is an impulse that comes from within and from outside a person to achieve his goals and needs. If a student wants to get good learning outcomes, then a student will fulfill his needs by studying earnestly. High student learning motivation will get high learning outcomes as well.

On the contrary, if student learning motivation is low, student learning outcomes are also low. Irsyad and Fauzy (2021) said that learning motivation is important for every student to have in their learning activities. Motivation will give encouragement and foster students' enthusiasm to learn various things, especially biology lessons. So with the motivation to learn, students will try to learn the lesson seriously to achieve the subject's objectives.

This research is in line with Damopolii (2017) that learning motivation has a relationship with student biology learning outcomes and the contribution to learning outcomes. The higher the motivation to learn, the better the learning outcomes. In addition, it is also in line with the results of Irsyad and Fauzy (2021), which states that there is a positive relationship between learning motivation and student biology learning outcomes. Motivation to learn with learning outcomes has a moderate level of correlation. The relationship between the two is positive, meaning that the higher the motivation to learn, the higher the learning outcomes will be.

\section{CONCLUSION}

Based on the data analysis and the results of the research that has been done, it can be concluded that there is a significant relationship between motivation and learning outcomes of biology through distance learning at one high school in Indonesia with the value of the intrinsic motivation correlation coefficient (X1) 0.86 and the correlation coefficient extrinsic motivation (X2) 0.85 . The results of the t-test obtained the results tcount $=15.27>$ table 1.66 for variable $\mathrm{X} 1$ and tcount $14.47>\mathrm{t}$ table 1.66 for variable $\mathrm{X} 2$. The coefficient of determination of the intrinsic motivation variable (X1) is $75 \%$, and the extrinsic motivation variable (X2) is $73 \%$. This means that $75 \%$ of intrinsic motivation and $73 \%$ of extrinsic motivation contribute to student biology learning outcomes (Y) during the implementation of distance learning.

\section{SUGGESTIONS}

Based on the results of the research, discussion, and conclusions that have been obtained, the following suggestions can be submitted:

1. The results of this study should be used as a reference for schools to evaluate the implementation of online learning in order to increase students' learning motivation. 
2. For readers, this research should be used as an additional reference to examine the same problem regarding the relationship between learning motivation and learning outcomes, especially in distance learning.

\section{ACKNOWLEDGEMENTS}

Authors thank for the Biology Education Study Program, Faculty of Teacher Training and Education, Bung Hatta University, and the research school, namely SMAN 1 Ulakan Tapakis, Padang Paariaman Regency, Indonesia who have facilitated the author in carrying out this research.

\section{REFERENCES}

Cahyani, A., Listiana, I. D., \& Larasati, S. P. D. (2020). Learning Motivation of High School Students in Online Learning in the Covid-19 Pandemic Period IQ (Science of the Qur'an): Journal of Islamic Education, 3(01), 123-140.

Damopolii, I., \& Lefaan, P. T. (2018). The Relationship between Learning Motivation and Student Biology Learning Outcomes at SMP 21 Rendani Manokwari.

Irsyad, F. M., \& Fauzi, S. (2021). The Relationship Between Learning Motivation and Student Learning Outcomes in Biology Lessons in Class X Madrasah Aliyah Negeri (MAN) Tasikmalaya. Bioed: Journal of Biological Education, 8(1), 15-21.

Maryam, M. (2016). The Influence of Motivation in Learning. Lanthanide Journal, 4(2), 8897.

Sardiman A.M. (2014). Interaction and Teaching and Learning Motivation. Jakarta: Rajawali Press.

Sugiyono. (2016). Qualitative Quantitative Research Methods and R\&D. Bandung : Alphabeta Publisher. 